American Journal of Applied Sciences 5 (9): 1091-1106, 2008

ISSN 1546-9239

(C) 2008 Science Publications

\title{
Uptake and Translocation of Iron by Native Tree Species In A Constructed Wetland Treating Landfill Leachates
}

\author{
${ }^{1}$ A. Snow, ${ }^{1}$ A. E. Ghaly, ${ }^{2}$ R. Cote and ${ }^{1}$ A.M. Snow \\ ${ }^{1}$ Department of Process Engineering and Applied Science \\ ${ }^{2}$ School for Resource and Environmental Studies Dalhousie University, \\ Halifax, Nova Scotia, Canada
}

\begin{abstract}
A surface flow wetland was constructed in the Burnside Industrial Park, Dartmouth, Nova Scotia, to treat stormwater runoff from the surrounding watersheds which are comprised primarily of commercial properties and two former landfills. The objectives of this study were: (a) to compare the uptake of iron by red maple, white birch and red spruce trees growing under flooded soil conditions in the constructed wetland and well drained soil conditions in a nearby reference site, (b) to evaluate the seasonal variability of iron in these trees and (c) to determine the distribution of iron in different compartments of these trees (leaves, twigs, branches, trunk wood, trunk bark and roots). The average iron concentrations in the aboveground compartments of red maple, white birch and red spruce trees were within the range of iron concentrations reported in the literature for these trees. Red maple, white birch and red spruce trees in the constructed wetland had significantly greater iron concentrations in their roots than the same species in the reference site. The average iron concentrations in the leaves of red maple trees in the constructed wetland and the reference site displayed an increasing trend towards the end of the growing season while the average iron concentrations in the twigs of red maple and white birch trees in the constructed wetland and the reference site displayed maximum concentrations at the beginning of the growing season. Red maple, white birch and red spruce trees in the constructed wetland retained a major portion of their overall iron concentration in their root systems.
\end{abstract}

Key words: Red maple, white birch, red spruce, iron, seasonal variability and constructed wetland

\section{INTRODUCTION}

Heavy metals are elements that have the ability to be easily molded or shaped, conduct heat and electricity and form stable cations. Air, water and soil environments may become polluted with high concentrations of heavy metals from both natural sources such as volcanoes, forest fires and mineral outcrops, and anthropogenic sources such as industrial activities, agricultural practices, atmospheric deposition and waste disposal operations ${ }^{[1-3]}$. Contamination of the environment by heavy metals can have significant impacts on both human health and ecosystems ${ }^{[4-6]}$.

Current remediation methods for heavy metal contaminated environments are often expensive and physically invasive $e^{[7]}$. Soil remediation typically relies on physical and chemical technologies. Physical approaches isolate contaminants from the surrounding environment using capping systems and in situ vertical barriers. However, these technologies do not remove the contaminants from the soil matrix. Chemical soil remediation relies on extraction techniques such as soil washing with strong acids or solidification/stabilization with binder agents such as cement, which destroy all biological activity within the $\operatorname{soil}^{[8]}$. Wastewater remediation relies on the addition of chemical agents to the water and physical settling of metal contaminated sludge, which poses the problem of sludge disposal. Therefore, within the last fifteen years, efforts have been directed towards finding biological strategies for remediation of metal contaminated environments that are less expensive and less invasive. One such method is phytoremediation ${ }^{[7]}$.

Phytoremediation is a passive technology that takes advantage of the natural processes of aquatic and terrestrial plants and microbial rhizosphere populations (bacteria and fungi) to stabilize, sequester, accumulate and/or metabolize organic and inorganic contaminants

Corresponding author: A. E. Ghaly, Professor, Department of Process Engineering and Applied Science, Dalhousie Universiy, Halifax, Nova Scotia, Canada Tel: (902) 494-6014 Fax: (902) 420-7639. 
in polluted soils, sludges, sediments, groundwater, surface water and wastewater ${ }^{[9]}$. Plants extract metals from their soil and water environments because many metals including magnesium, calcium, potassium, iron, manganese, copper, zinc, and molybdenum are essential nutrients. Plants also extract metals from their soil and water environments that have not been recognized as essential nutrients including chromium, lead, cadmium, mercury and nickel ${ }^{[10,11]}$. Metal phytoremediation techniques that have been extensively studied include the use of hyperaccumulator plants ${ }^{[12-14]}$, high biomass crop plants with chelate addition to enhance metal extraction $^{[15,16]}$, aquatic plants ${ }^{[17,18]}$ and fast growing trees ${ }^{[19,20]}$.

The use of trees to remediate heavy metal contaminated environments has several advantages: (a) trees are long lived plants with high biomass production and, therefore, have the potential to extract large concentrations of heavy metals from contaminated land and store them in woody tissues where they are less bioavailable $^{[21]}$, (b) trees form dense vegetative covers and have large and deep root systems, which stabilize soils and reduce mobility of contaminants ${ }^{[22]}$ and (c) trees are an economic resource that can be used for the manufacture of timber products or for the production of heat, electricity and fuel ${ }^{[23]}$.

The objectives of this study were: (a) to compare the uptake of iron by native tree species growing under flooded soil conditions in a constructed wetland and well drained soil conditions in a nearby forest, (b) to evaluate the seasonal variability of iron in these trees and (c) to determine the distribution of iron in different compartments of these trees (leaves, twigs, branches, trunk wood, trunk bark and roots).

\section{MATERIALS AND METHODS}

Burnside constructed wetland: A surface flow constructed wetland was established in the Burnside Industrial Park, Dartmouth, Nova Scotia, to treat stormwater runoff from the surrounding watersheds which are comprised primarily of commercial properties and two former landfills (a 5.34 ha site that operated from 1968 to 1974 and a 5.42 ha site that operated from 1976 to 1977 ). The aim was to protect a freshwater ecosystem that consists of a $4.6 \mathrm{~km}$ long brook (Wright's Brook) and two lakes (Enchanted Lake and Flat Lake). A previously conducted environmental site assessment (Table 1) had determined that the water entering the brook contained average iron and manganese concentrations (15.508 and $3.029 \mathrm{mg} \mathrm{L}^{-1}$ respectively) which exceed the allowable limits

\begin{tabular}{lcr} 
Table 1: Heavy metal loads entering Wright's Brook \\
Element & $\begin{array}{c}\text { Average } \\
\text { Concentration } \\
\left(\mathrm{mg} \mathrm{L}^{-1}\right)\end{array}$ & $\begin{array}{c}\text { Guidelines } \\
\left(\mathrm{mg} \mathrm{L}^{-1}\right)\end{array}$ \\
\hline Aluminium & 7.720 & $0.005-0.100$ \\
Arsenic & 0.009 & 0.005 \\
Chromium & 0.013 & $0.001-0.009$ \\
Copper & 0.039 & $0.002-0.004$ \\
Iron & 15.508 & 0.300 \\
Lead & 0.075 & $0.001-0.007$ \\
Manganese & 3.029 & $1.000-1.500^{[25]}$ \\
Zinc & 0.158 & 0.030 \\
\hline
\end{tabular}

established by the Canadian Water Quality Guidelines for the Protection of Aquatic Life ${ }^{[24,25]}$. The wetland consists of 9 deep open water cells that are separated by shallow internal vegetated berms and surrounded by a system of external berms with a surface area of $6300 \mathrm{~m}^{2}$ and 2 naturally vegetated islands that are surrounded by a system of external berms with a surface area of approximately $6100 \mathrm{~m}^{2}$. The wetland berms and cells were planted with a variety of native plant species such as Carex crinita (fringed sedge), Carex lurida (yellow green sedge), Juncus brevicaudatus (tweedy's rush), Juncus effusus (soft rush), Scripus validus (soft stem bulrush), Calamagrostis canadensis (bluejoint grass), Alisma plantagoaquatica (water plantain), Pontederia cordata (pickerelweed), Nymphaea alba (white waterlily) and Potamageton natans (pondweed). The two naturally vegetated islands consist of untamed early successional brush dominated by low shrubs such as Comptonia peregrina (sweet fern), Viburnum cassinoides (witherod) and Spiraea alba (meadowsweet), deciduous and evergreen trees such as Acer rubrum (red maple), Betula papyrifera (white birch) and Picea rubens (red spruce) and emergent macrophytes such as Typha latifolia (cattails).

Selection of trees and sampling locations: A survey of the vegetated islands was conducted in order to identify dominant tree species. Based on the survey, two deciduous and one evergreen tree species were selected for this study. The two deciduous species included: Acer rubrum (red maple) and Betula papyrifera (white birch) and the evergreen species was Picea rubens (red spruce).

Samples of leaves, twigs, branches, trunk bark, trunk wood and roots from trees were collected from the two naturally vegetated islands in the constructed wetland and from a reference site. The reference site was a forested area located to the south west of the islands. It was not influenced by stormwater runoff or leachate from the former landfills and it was never flooded during the study period. According to 


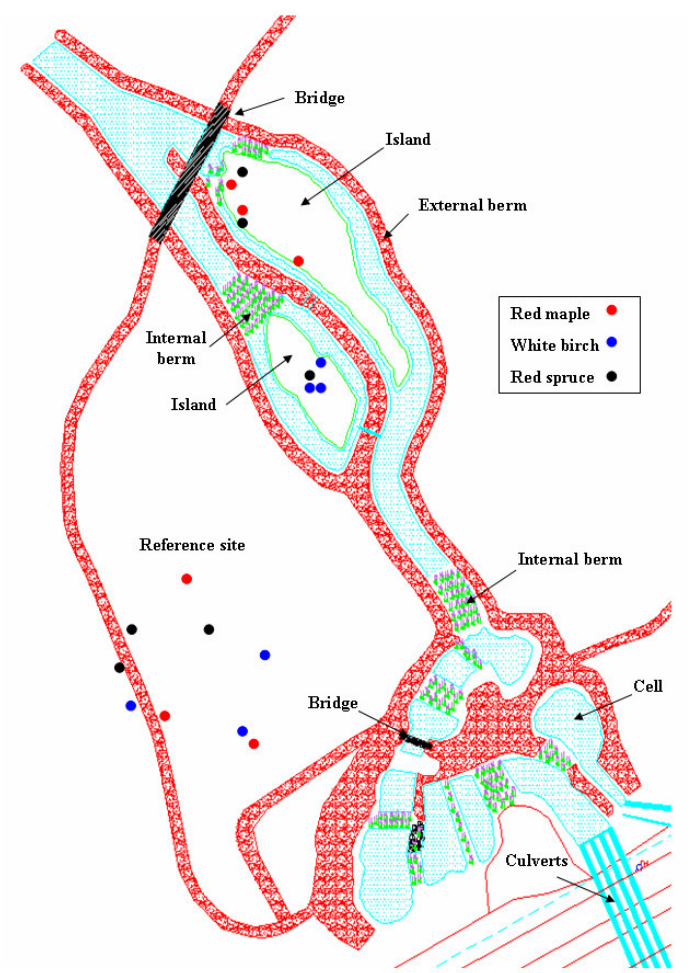

Fig. 1: Location of sampled trees

MacDougall et al. ${ }^{[26]}$, the soil in the reference site was porous and well drained. A total of six trees from each of red maple, white birch and red spruce were sampled (three trees from the naturally vegetated islands and three trees from the reference site). The sampling locations are shown in Fig. 1.

Sample collection: In season one, plant samples were collected when element concentrations were most stable. Element concentrations in evergreen species are most stable during the dormant season, which is typically from September through early March while element concentrations in deciduous species are most stable late in the growing season approximately two weeks before the onset of autumn coloration ${ }^{[27]}$. Therefore, plant samples were collected during the second and third weeks of September 2005. In season two, plant samples were collected in June 2006, July 2006 and August 2006. Samples of leaves were also collected in September and October 2006 upon senescence.

Samples of leaves, twigs and branches were collected with hand pruners, long handled pruners and a telescopic pruning pole. For both evergreen and deciduous species, samples of leaves or needles were whole, well formed and current year's growth and were collected from several branches representing various sides of the middle part of the live crown of each tree. Approximately 20 leaves per deciduous tree were collected and mixed to make one sample. Enough needles and twigs were collected per evergreen tree to fill an $18 \times 15 \mathrm{~cm}$ plastic bag. To minimize serious injury to the trees, only one branch per tree was collected, cut into 6 inch lengths and mixed to make one sample. Wood and bark samples were collected from the trunk of each tree at breast height $(1.3 \mathrm{~m})$. An axe was used to peel off a sample of bark and a $25.4 \mathrm{~cm}$ increment borer (SUUNTO, Vantaa, Finland) with three threads and an inner bit diameter of $5 \mathrm{~mm}$ was used to collect a wood core. Two parallel wood cores were obtained from each sampled trunk and mixed to make one sample. Samples of roots were collected from each tree in an area between the outer branch tips and trunk. A stainless steel spade was used to expose a portion of roots around each tree and samples were collected using long handled pruners. Samples were placed in labeled resealable plastic bags and stored in a cooler $\left(5^{\circ} \mathrm{C}\right)$. All samples were transported to the laboratory within 8 hours and stored in a refrigerator at $4^{\circ} \mathrm{C}$.

Sample preparation: Preparation of plant samples involved decontamination, oven drying and particle size reduction.

Decontamination: According to Mills and Jones Jr. ${ }^{[10]}$, when plant materials are covered with soil, dust particles or spray materials, decontamination is required. Horwitz ${ }^{[28]}$ stated that the decontamination process should be performed quickly and excess washing of plant tissue, especially leaves, should be avoided to prevent leaching of minerals. However, tissue exposed to frequent rainfall such as leaves, twigs and branches need not be washed. Therefore, only root samples were washed with tap water to remove soil prior to drying.

Oven drying: Plant materials should be dried to minimize decomposition or weight loss by respiration at a temperature high enough to destroy the enzymes responsible for decomposition and sufficient for moisture removal, but below the temperature of thermal decomposition. Enzymes present in plant tissues are inactivated at temperatures above $60^{\circ} \mathrm{C}^{[29]}$. Therefore, plant tissues were placed in brown paper bags and oven dried at a temperature of $80^{\circ} \mathrm{C}$ for approximately $48 \mathrm{~h}$ in a laboratory oven (Isotemp® Oven, Model \# 655F, Fisher Scientific Co., Ontario, Canada). 
Particle size reduction: Samples of leaves were removed from the brown paper bags and placed into resealable plastic bags and reduced in size by manually crushing the dried samples. Samples of twigs, trunk bark and trunk wood were reduced in size by hand cutting using hand pruners and then by grinding in a coffee grinder (Toastmaster®, Model \# 1119CAN, China). Samples of branches and roots were reduced in size by hand cutting using long handled pruners and then by grinding in the coffee grinder.

Sample analyses: Prepared samples were stored in air tight plastic containers in a refrigerator $\left(4^{\circ} \mathrm{C}\right)$ until they were delivered to the Minerals Engineering Center at Dalhousie University, Halifax, Nova Scotia and analyzed for total iron concentrations.

Total iron: A wet acid digestion procedure was performed for destruction of organic matter present in plant samples. Initially, $1.0 \mathrm{~g}$ of dried, ground sample was placed in a Teflon beaker and $30 \mathrm{~mL}(38 \% \mathrm{HCl})$ hydrochloric acid (Cat. \# A144-S212, Fisher Scientific Co., Ontario, Canada), $10 \mathrm{~mL}\left(70 \% \mathrm{HNO}_{3}\right)$ nitric acid (Cat. \# A200-212, Fisher Scientific Co., Ontario, Canada), $10 \mathrm{~mL}(49 \% \mathrm{HF})$ hydrofluoric acid (Cat. \# A147-1LB, Fisher Scientific Co., Ontario, Canada) and $5 \mathrm{~mL}\left(70 \% \mathrm{HCLO}_{4}\right)$ perchloric acid (Cat. \# A2296-1LB, Fisher Scientific Co., Ontario, Canada) were added. Under a fume hood, the samples were heated to dryness (overnight) on a hot plate (Model \# SP46925, Barnstead/Thermolyne, Dubuque, Iowa) at a temperature of $125^{\circ} \mathrm{C}$. Then, $10 \mathrm{~mL}$ of $\mathrm{HCl}$ and $30 \mathrm{~mL}$ of $\mathrm{H}_{2} \mathrm{O}$ were added to dissolve the residue. Under a fume hood, the samples were heated on a hot plate at a temperature of $125{ }^{\circ} \mathrm{C}$ for 30 minutes. The samples were filtered through Fisher \# 4 filter paper (Cat. \# 09-803-6A, Fisher Scientific Co., Ontario, Canada) and the filtrate was collected in a $100 \mathrm{~mL}$ volumetric glass flask and made up to a final volume of $100 \mathrm{~mL}$ with distilled-deionized water.

Iron concentrations were determined by inductively coupled plasma-optical emission spectroscopy (Vista Pro, Varian Inc., Victoria, Australia) with a detection limit of $1.00 \mathrm{ppm}$ for $\mathrm{Fe}$.

\section{RESULTS AND DISCUSSION}

Uptake of iron: Iron is an essential micronutrient that is required for plant growth. According to Decoteau ${ }^{[30]}$, iron is involved in the synthesis of chlorophyll, chloroplast proteins and various enzymes. Symptoms of inadequate iron nutrition include chlorosis of young leaves and stunted root growth. Uptake of excess quantities of iron by plants can be potentially toxic because iron promotes the formation of reactive oxygen based radicals that are able to damage cellular membranes. The roots of plants exposed to excess concentrations of iron undergo blackening ${ }^{[31]}$. The iron concentrations in the different compartments of each tree are shown in Tables 2-4. Tables 5-7 display the analysis of variance for the total iron concentrations in the compartments of red maple, white birch and red spruce trees, respectively as affected by location.

Leaves: The average iron concentrations in the leaves of red maple, white birch and red spruce trees in the constructed wetland ranged from 124 to $321 \mathrm{mg} \mathrm{kg}^{-1}$, from 117 to $172 \mathrm{mg} \mathrm{kg}^{-1}$ and from 105 to $166 \mathrm{mg} \mathrm{kg}^{-1}$, respectively. The average iron concentrations in the leaves of red maple, white birch and red spruce trees in the reference site ranged from 102 to $147 \mathrm{mg} \mathrm{kg}^{-1}$, from 125 to $193 \mathrm{mg} \mathrm{kg}^{-1}$ and from 46 to $200 \mathrm{mg} \mathrm{kg}^{-1}$, respectively.

Piczak $^{[33]}$, Kozlov et al. ${ }^{[34]}$ and Heinrichs and Mayer ${ }^{[35]}$ observed average iron concentrations of $128-300 \mathrm{mg} \mathrm{kg}^{-1}, 154-350 \mathrm{mg} \mathrm{kg}^{-1}$ and $210 \mathrm{mg} \mathrm{kg}^{-1}$ in the leaves of Norway maple, mountain birch and Norway spruce trees, respectively. Reeves and Baker ${ }^{[36]}$ stated that the low, normal and high concentrations of iron in dried plant leaves are $10 \mathrm{mg} \mathrm{kg}{ }^{-1}, 60-600 \mathrm{mg}$ $\mathrm{kg}^{-1}$ and $2500 \mathrm{mg} \mathrm{kg}^{-1}$, respectively. The average iron concentrations in the leaves of the sampled trees fell within the normal range for iron in dried plant leaves.

The statistical analysis showed that only the concentrations of iron in the leaves of red maple trees in the constructed wetland were significantly greater than those in the leaves of red maple trees in the reference site $(\mathrm{p}$-value $=0.004)$. Moorhead and McArthur ${ }^{[32]}$ observed greater iron concentrations in the leaves of red maple trees growing in saturated soils as opposed to well drained soils and concluded that the higher concentration of iron in the leaves of red maple trees growing in saturated soils was due to the greater availability of reduced iron in saturated soil conditions.

Twigs: The average iron concentrations in the twigs of red maple, white birch and red spruce trees in the constructed wetland ranged from 73 to $348 \mathrm{mg} \mathrm{kg}^{-1}$, from 53 to $282 \mathrm{mg} \mathrm{kg}^{-1}$ and from 271 to $360 \mathrm{mg} \mathrm{kg}^{-1}$, respectively. The average iron concentrations in the twigs of red maple, white birch and red spruce trees in the reference site ranged from 53 to $355 \mathrm{mg} \mathrm{kg}^{-1}$, from 71 to $304 \mathrm{mg} \mathrm{kg}^{-1}$ and from 334 to $437 \mathrm{mg} \mathrm{kg}^{-1}$, respectively. 
Am. J. Applied Sci., 5 (9): 1091-1106, 2008

Table 2: Average Fe concentrations $\left(\mathrm{mg} \mathrm{kg}^{-1}\right)$ in various compartments of red maple trees

\begin{tabular}{|c|c|c|c|c|c|c|c|c|c|c|c|}
\hline \multirow{3}{*}{ Compartment } & \multirow{3}{*}{$\mathrm{n}$} & \multicolumn{5}{|c|}{ Wetland } & \multicolumn{5}{|c|}{ Reference } \\
\hline & & \multirow{2}{*}{$\begin{array}{l}2005 \\
\text { Sept }\end{array}$} & \multicolumn{4}{|c|}{2006} & \multirow{2}{*}{$\begin{array}{l}2005 \\
\text { Sept }\end{array}$} & \multicolumn{4}{|c|}{2006} \\
\hline & & & Jun & Jul & Aug & Sept & & Jun & Jul & Aug & Sept \\
\hline \multirow[t]{2}{*}{ Leaves } & 3 & 168 & 157 & 124 & 321 & 247 & 116 & 130 & 102 & 147 & 144 \\
\hline & & (36) & (8) & (33) & (117) & (59) & (9) & (23) & (24) & (11) & (18) \\
\hline \multirow[t]{2}{*}{ Twigs } & 3 & 348 & 242 & 91 & 73 & - & 355 & 164 & 61 & 53 & - \\
\hline & & (154) & (87) & (30) & (29) & - & (275) & (29) & (17) & (8) & - \\
\hline \multirow[t]{2}{*}{ Branches } & 3 & 73 & 139 & 31 & 63 & - & 49 & 115 & 29 & 37 & - \\
\hline & & (29) & (158) & (8) & (19) & - & (10) & (59) & (10) & (20) & - \\
\hline \multirow[t]{2}{*}{ Trunk Wood } & 3 & 205 & 70 & 70 & 26 & - & 362 & 80 & 30 & 14 & - \\
\hline & & (28) & (33) & (85) & (2) & - & (130) & (25) & (11) & (3) & - \\
\hline \multirow[t]{2}{*}{ Trunk Bark } & 3 & 221 & 91 & 126 & 168 & - & 147 & 87 & 253 & 111 & - \\
\hline & & (111) & (65) & (22) & (33) & - & (53) & (24) & (90) & (49) & - \\
\hline \multirow[t]{2}{*}{ Roots } & 3 & 311 & - & - & 2091 & - & 218 & - & - & 54 & - \\
\hline & & (161) & - & - & (763) & - & (187) & - & - & (35) & - \\
\hline
\end{tabular}

- Samples were not collected () Standard deviation

Table 3: Average Fe concentrations $\left(\mathrm{mg} \mathrm{kg}^{-1}\right)$ in various compartments of white birch trees

\begin{tabular}{|c|c|c|c|c|c|c|c|c|c|c|c|}
\hline \multirow{3}{*}{ Compartment } & \multirow{3}{*}{$\mathrm{n}$} & \multicolumn{5}{|c|}{ Wetland } & \multicolumn{5}{|c|}{ Reference } \\
\hline & & \multirow{2}{*}{$\frac{2005}{\text { Sept }}$} & \multicolumn{4}{|c|}{2006} & \multirow{2}{*}{$\frac{2005}{\text { Sept }}$} & \multicolumn{4}{|c|}{2006} \\
\hline & & & Jun & Jul & Aug & Sept & & Jun & Jul & Aug & Sept \\
\hline \multirow[t]{2}{*}{ Leaves } & 3 & 169 & 117 & 130 & 154 & 172 & 193 & 130 & 125 & 172 & 120 \\
\hline & & (64) & (15) & (33) & (33) & (7) & (3) & (41) & (51) & (18) & (45) \\
\hline \multirow[t]{2}{*}{ Twigs } & 3 & 282 & 176 & 83 & 53 & - & 304 & 84 & 71 & 77 & - \\
\hline & & (121) & (35) & (12) & (8) & - & (37) & (17) & (17) & (30) & - \\
\hline \multirow[t]{2}{*}{ Branches } & 3 & 41 & 115 & 70 & 40 & - & 49 & 77 & 79 & 45 & - \\
\hline & & (17) & (99) & (49) & (13) & - & (12) & (56) & (46) & (18) & - \\
\hline \multirow[t]{2}{*}{ Trunk Wood } & 3 & 257 & 120 & 68 & 68 & - & 197 & 119 & 43 & 22 & - \\
\hline & & (217) & (76) & (83) & (46) & - & (157) & (57) & (33) & (9) & - \\
\hline \multirow[t]{2}{*}{ Trunk Bark } & 3 & 99 & 188 & 271 & 293 & - & 39 & 244 & 159 & 117 & - \\
\hline & & (86) & (38) & (129) & (224) & - & (10) & (140) & (34) & (59) & - \\
\hline \multirow[t]{2}{*}{ Roots } & 3 & 336 & - & - & 845 & - & 89 & - & - & 122 & - \\
\hline & & (190) & - & - & (494) & - & (34) & - & - & (75) & - \\
\hline
\end{tabular}

- Samples were not collected () Standard deviation

Table 4: Average Fe concentrations $\left(\mathrm{mg} \mathrm{kg}^{-1}\right)$ in various compartments of red spruce trees

\begin{tabular}{|c|c|c|c|c|c|c|c|c|c|}
\hline \multirow{3}{*}{ Compartment } & \multirow{3}{*}{$\mathrm{n}$} & \multicolumn{4}{|c|}{ Wetland } & \multicolumn{4}{|c|}{ Reference } \\
\hline & & \multirow{2}{*}{$\begin{array}{l}2005 \\
\text { Sept }\end{array}$} & \multicolumn{3}{|c|}{2006} & \multirow{2}{*}{$\begin{array}{l}2005 \\
\text { Sept }\end{array}$} & \multicolumn{3}{|c|}{2006} \\
\hline & & & Jun & Jul & Aug & & Jun & Jul & Aug \\
\hline \multirow[t]{2}{*}{ Leaves } & 3 & 166 & 132 & 105 & 158 & 99 & 200 & 46 & 76 \\
\hline & & (66) & (30) & (51) & (86) & (26) & (168) & (8) & (12) \\
\hline \multirow[t]{2}{*}{ Twigs } & 3 & 283 & 271 & 322 & 360 & 437 & 334 & 390 & 383 \\
\hline & & (59) & (117) & (119) & (109) & (91) & (49) & (142) & (44) \\
\hline \multirow[t]{2}{*}{ Branches } & 3 & 196 & 183 & 77 & 148 & 209 & 234 & 173 & 181 \\
\hline & & (95) & (56) & (35) & (66) & (31) & (44) & (114) & (31) \\
\hline \multirow[t]{2}{*}{ Trunk Wood } & 3 & 142 & 26 & 46 & 50 & 196 & 70 & 29 & 12 \\
\hline & & (10) & (9) & (42) & (16) & (46) & (34) & (4) & (1) \\
\hline \multirow[t]{2}{*}{ Trunk Bark } & 3 & 424 & 98 & 316 & 171 & 145 & 168 & 229 & 121 \\
\hline & & $(50)$ & (65) & (163) & (58) & (37) & $(58)$ & (142) & (27) \\
\hline \multirow[t]{2}{*}{ Roots } & 3 & 1063 & - & - & 851 & 139 & - & - & 81 \\
\hline & & (984) & - & - & (452) & (87) & - & - & (26) \\
\hline
\end{tabular}


Am. J. Applied Sci., 5 (9): 1091-1106, 2008

\begin{tabular}{|c|c|c|c|c|c|}
\hline Source & DF & SS & MS & $\mathrm{F}$ & $\mathrm{P}$ \\
\hline \multicolumn{6}{|c|}{ Red maple leaves } \\
\hline Total & 29 & 166835 & & & \\
\hline Location & 1 & 43168 & 43168 & 9.77 & 0.004 \\
\hline Error & 28 & 123667 & 4417 & & \\
\hline \multicolumn{6}{|c|}{ Red maple twigs } \\
\hline Total & 23 & 556199 & & & \\
\hline Location & 1 & 5400 & 5400 & 0.22 & 0.647 \\
\hline Error & 22 & 550799 & 25036 & & \\
\hline \multicolumn{6}{|c|}{ Red maple branches } \\
\hline Total & 23 & 95438 & & & \\
\hline Location & 1 & 2128 & 2128 & 0.50 & 0.486 \\
\hline Error & 22 & 93310 & 4241 & & \\
\hline \multicolumn{6}{|c|}{ Red maple trunk wood } \\
\hline Total & 23 & 350673 & & & \\
\hline Location & 1 & 4817 & 4817 & 0.31 & 0.585 \\
\hline Error & 22 & 345857 & 15721 & & \\
\hline \multicolumn{6}{|c|}{ Red maple trunk bark } \\
\hline Total & 23 & 140930 & & & \\
\hline Location & 1 & 14 & 14 & 0.00 & 0.964 \\
\hline Error & 22 & 140916 & 6405 & & \\
\hline \multicolumn{6}{|c|}{ Red maple roots } \\
\hline Total & 11 & 9487207 & & & \\
\hline Location & 1 & 3404805 & 3404805 & 5.60 & 0.040 \\
\hline Error & 10 & 6082402 & 608240 & & \\
\hline \multicolumn{6}{|c|}{ Differences are considered significant at a p-value $\leq 0.05$ (95\% confidence interval) } \\
\hline Source & DF & SS & MS & $\mathrm{F}$ & $\mathrm{P}$ \\
\hline \multicolumn{6}{|c|}{ White birch leaves } \\
\hline Total & 29 & 46157 & & & \\
\hline Location & 1 & 1 & 1 & 0.00 & 0.982 \\
\hline Error & 28 & 46156 & 1648 & & \\
\hline \multicolumn{6}{|c|}{ White birch twigs } \\
\hline Total & 23 & 251329 & & & \\
\hline Location & 1 & 1233 & 1233 & 0.11 & 0.745 \\
\hline Error & 22 & 250097 & 11368 & & \\
\hline \multicolumn{6}{|c|}{ White birch branches } \\
\hline Total & 23 & 50948 & & & \\
\hline Location & 1 & 117 & 117 & 0.05 & 0.824 \\
\hline Error & 22 & 50831 & 2310 & & \\
\hline \multicolumn{6}{|c|}{ White birch trunk wood } \\
\hline Total & 23 & 317090 & & & \\
\hline Location & 1 & 6633 & 6633 & 0.47 & 0.500 \\
\hline Error & 22 & 310457 & 14112 & & \\
\hline \multicolumn{6}{|c|}{ White birch trunk bark } \\
\hline Total & 23 & 367718 & & & \\
\hline Location & 1 & 31901 & 31901 & 2.09 & 0.162 \\
\hline Error & 22 & 335817 & 15264 & & \\
\hline \multicolumn{6}{|c|}{ White birch roots } \\
\hline Total & 11 & 1669144 & & & \\
\hline Location & 1 & 704705 & 704705 & 7.31 & 0.022 \\
\hline Error & 10 & 964439 & 96444 & & \\
\hline
\end{tabular}

Differences are considered significant at a p-value $\leq 0.05$ (95\% confidence interval) 
Am. J. Applied Sci., 5 (9): 1091-1106, 2008

\begin{tabular}{|c|c|c|c|c|c|}
\hline Source & DF & SS & MS & $\mathrm{F}$ & $\mathrm{P}$ \\
\hline \multicolumn{6}{|c|}{ Red spruce needles } \\
\hline Total & 23 & 143191 & & & \\
\hline Location & 1 & 7526 & 7526 & 1.22 & 0.281 \\
\hline Error & 22 & 135665 & 6167 & & \\
\hline \multicolumn{6}{|c|}{ Red spruce twigs } \\
\hline Total & 23 & 217948 & & & \\
\hline Location & 1 & 35574 & 35574 & 4.29 & 0.050 \\
\hline Error & 22 & 182374 & 8290 & & \\
\hline \multicolumn{6}{|c|}{ Red spruce branches } \\
\hline Total & 23 & 116230 & & & \\
\hline Location & 1 & 13920 & 13920 & 2.99 & 0.098 \\
\hline Error & 22 & 102310 & 4650 & & \\
\hline \multicolumn{6}{|c|}{ Red spruce trunk wood } \\
\hline Total & 23 & 97926 & & & \\
\hline Location & 1 & 693 & 693 & 0.16 & 0.696 \\
\hline Error & 22 & 97233 & 4420 & & \\
\hline \multicolumn{6}{|c|}{ Red spruce trunk bark } \\
\hline Total & 23 & 381283 & & & \\
\hline Location & 1 & 44462 & 44462 & 2.90 & 0.102 \\
\hline Error & 22 & 336821 & 15310 & & \\
\hline \multicolumn{6}{|c|}{ Red spruce roots } \\
\hline Total & 11 & 4585089 & & & \\
\hline Location & 1 & 2153921 & 2153921 & 8.86 & 0.014 \\
\hline Error & 10 & 2431167 & 243117 & & \\
\hline
\end{tabular}

Differences are considered significant at a p-value $\leq 0.05$ (95\% confidence interval)

The average iron concentrations in the twigs of the sampled trees compare with reported values in the literature. Pastor and Bockheim ${ }^{[37]}$ observed average iron concentrations of 93 and $52 \mathrm{mg} \mathrm{kg}^{-1}$ in the twigs of sugar maple and trembling aspen trees. $\mathrm{McColl}^{[38]}$ observed average iron concentrations of $45 \mathrm{mg} \mathrm{kg}^{-1}$ in the twigs of blue gum eucalyptus trees. Brotherson and Osayande ${ }^{[39]}$ observed average iron concentrations of 166.4 and $146.2 \mathrm{mg} \mathrm{kg}^{-1}$ in the twigs of mountain mahogany and Utah juniper trees. Young and Guinn ${ }^{[40]}$ observed iron concentrations of 58, 27 and $254 \mathrm{mg} \mathrm{kg}^{-1}$ in the twigs of red maple, birch and red spruce trees respectively.

The statistical analysis showed that only the concentrations of iron in the twigs of red spruce trees in the constructed wetland were significantly greater than those in the twigs of red spruce trees in the reference site $(\mathrm{p}$-value $=0.050)$. A review of the literature revealed one study by Sailerova and Fedikow ${ }^{[41]}$ who reported that the average iron concentration in the twigs of black spruce trees was not influenced by site drainage characteristics.
Branches: The average iron concentrations in the branches of red maple, white birch and red spruce trees in the constructed wetland ranged from 31 to $139 \mathrm{mg}$ $\mathrm{kg}^{-1}$, from 40 to $115 \mathrm{mg} \mathrm{kg}{ }^{-1}$ and from 77 to $196 \mathrm{mg} \mathrm{kg} \mathrm{kg}^{-1}$, respectively. The average iron concentrations in the branches of red maple, white birch and red spruce trees in the reference site ranged from 29 to $115 \mathrm{mg} \mathrm{kg}^{-1}$, from 45 to $77 \mathrm{mg} \mathrm{kg}^{-1}$ and from 173 to $234 \mathrm{mg} \mathrm{kg}^{-1}$, respectively. There was no significant difference between the concentrations of iron in the branches of trees in the constructed wetland and the reference site.

The average concentrations of iron in the branches of the sampled trees were within the range of values reported in the literature. Morrison and $\operatorname{Hogan}^{[42]}$, Pastor and Bockheim ${ }^{[37]}$ and Wittwer et al. ${ }^{[43]}$ observed average iron concentrations of $46-49 \mathrm{mg} \mathrm{kg}^{-1}, 32 \mathrm{mg}$ $\mathrm{kg}^{-1}$ and $92 \mathrm{mg} \mathrm{kg}^{-1}$ in the branches of sugar maple, sugar maple and red pine trees, respectively. Young and Guinn ${ }^{[40]}$ observed iron concentrations of 78, 50 and $66 \mathrm{mg} \mathrm{kg}^{-1}$ in the branches of red maple, white birch and red spruce trees, respectively. 
Trunk wood: The average concentrations of iron in the trunk wood of red maple, white birch and red spruce trees in the constructed wetland ranged from 26 to $205 \mathrm{mg} \mathrm{kg}^{-1}$, from 68 to $257 \mathrm{mg} \mathrm{kg}^{-1}$ and from 26 to $142 \mathrm{mg} \mathrm{kg}{ }^{-1}$, respectively. The average concentrations of iron in the trunk wood of red maple, white birch and red spruce trees in the reference site ranged from 14 to $362 \mathrm{mg} \mathrm{kg}^{-1}$, from 22 to $97 \mathrm{mg} \mathrm{kg}^{-1}$ and from 12 to $196 \mathrm{mg} \mathrm{kg}^{-1}$, respectively. There was no significant difference between the concentrations of iron in the trunk wood of trees in the constructed wetland and the reference site.

Miller $^{[44]}$ stated that elements such as iron are typically present in dry wood at concentrations of $<100 \mathrm{mg} \mathrm{kg}^{-1}$. Esch et al. ${ }^{[45]}$ observed average iron concentrations of $8.8,12$ and $64 \mathrm{mg} \mathrm{kg}^{-1}$ in the trunk wood of birch, oak and beech trees. Morrison and Hogan ${ }^{[42]}$, Pastor and Bockheim ${ }^{[37]}$ and Schmitt et al. ${ }^{[46]}$ observed average iron concentrations of $19 \mathrm{mg} \mathrm{kg}^{-1}$, $9.3 \mathrm{mg} \mathrm{kg}^{-1}$ and $12 \mathrm{mg} \mathrm{kg}^{-1}$ in the trunk wood of sugar maple, sugar maple and white birch trees, respectively. However, iron concentrations greater than $100 \mathrm{mg} \mathrm{kg}^{-1}$ have also been reported in the literature. Heinrichs and Mayer ${ }^{[35]}$ observed average iron concentrations of 270 and $180 \mathrm{mg} \mathrm{kg}^{-1}$ in the trunk wood of European beech and Norway spruce trees.
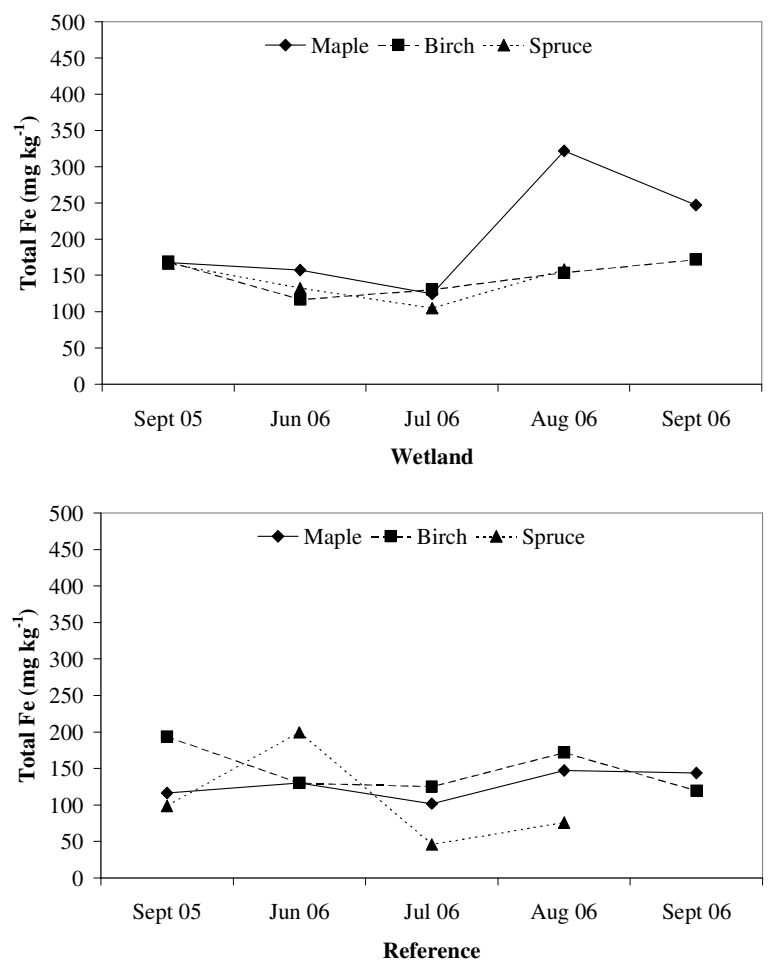

Fig. 2: Seasonal variations of Fe in leaves
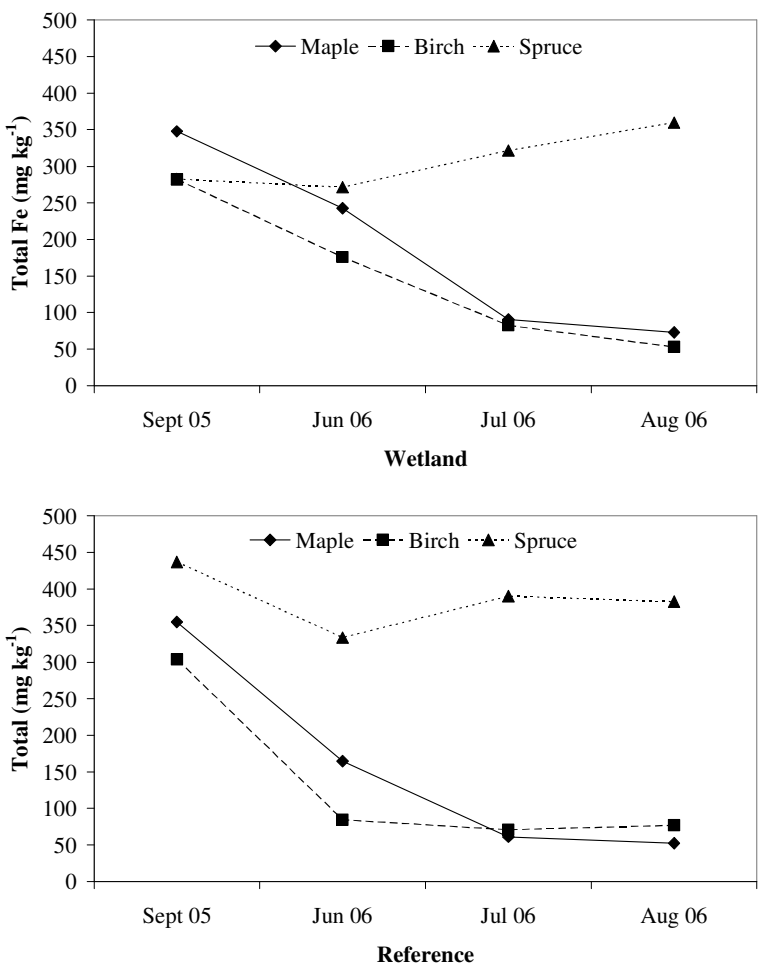

Fig. 3: Seasonal variations of Fe in twigs
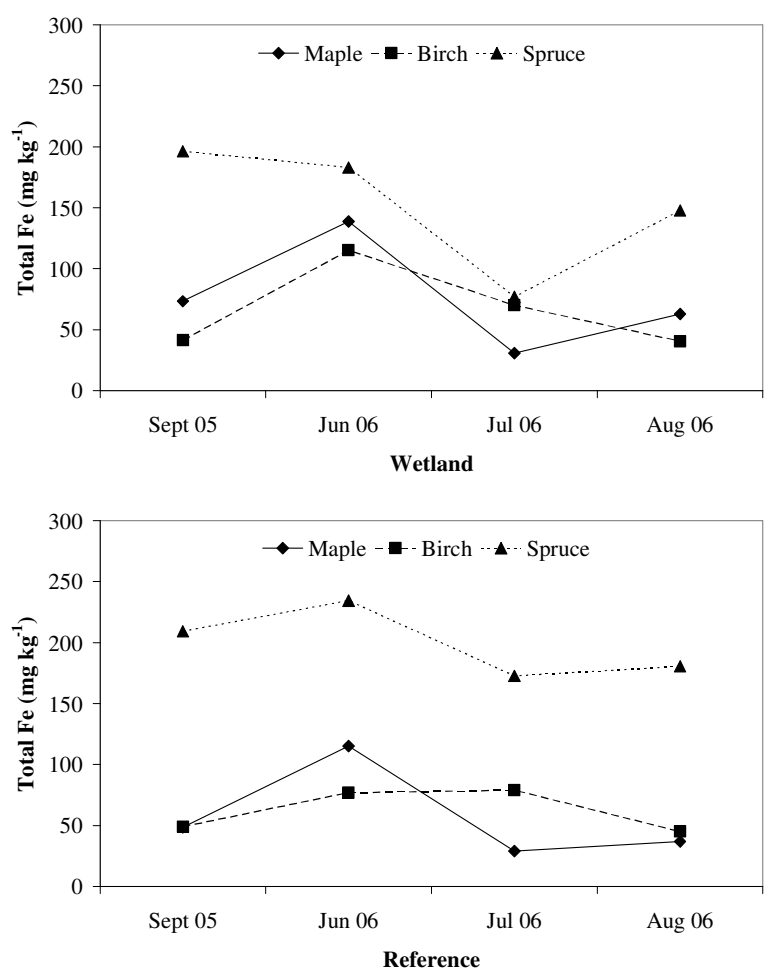

Fig. 4: Seasonal variations of Fe in branches 

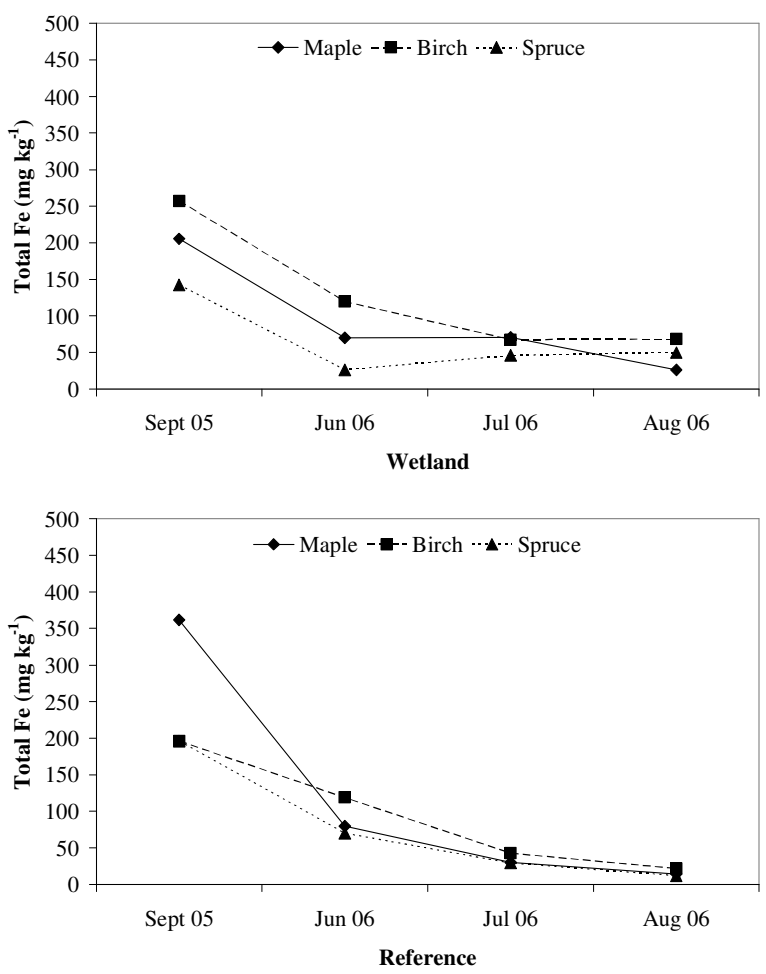

Fig. 5: Seasonal variations of Fe in trunk wood
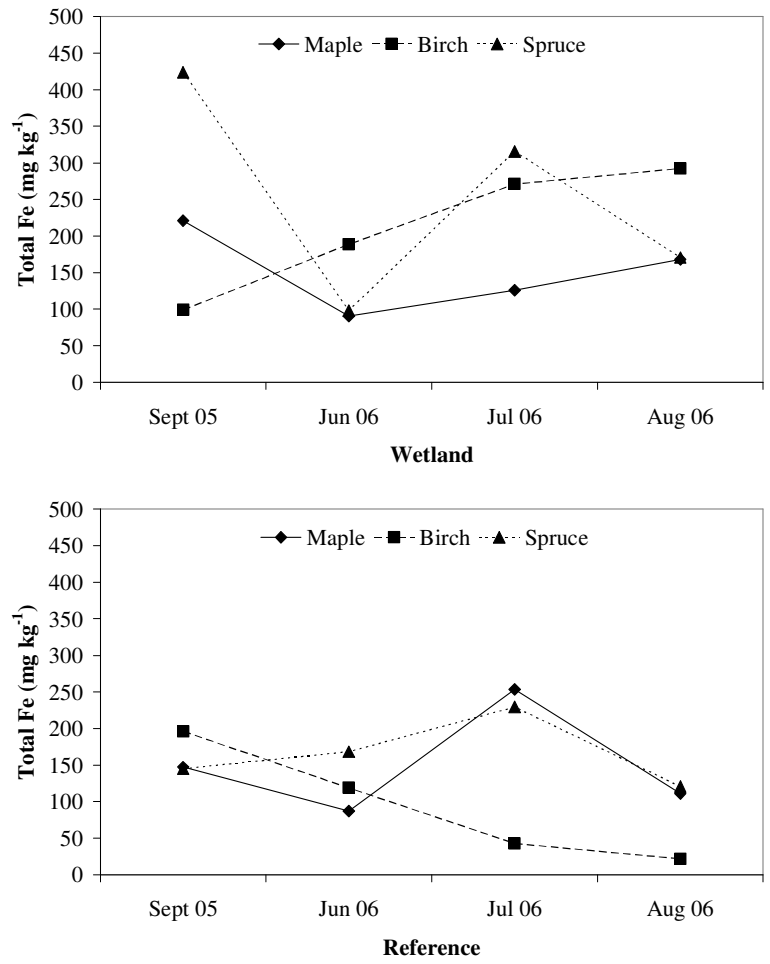

Fig. 6: Seasonal variations of Fe in trunk bark
Roots: The average concentrations of iron in the roots of red maple, white birch and red spruce trees in the constructed wetland during the second sampling period were $2091 \mathrm{mg} \mathrm{kg}^{-1}, 845 \mathrm{mg} \mathrm{kg}^{-1}$ and $851 \mathrm{mg} \mathrm{kg}^{-1}$, respectively. The average concentrations of iron in the roots of red maple, white birch and red spruce trees in the reference site during the second sampling period were $54 \mathrm{mg} \mathrm{kg}^{-1}, 122 \mathrm{mg} \mathrm{kg}^{-1}$ and $81 \mathrm{mg} \mathrm{kg}^{-1}$, respectively.

Vogt et al. ${ }^{[48]}$ observed average iron concentrations of 150 and $110 \mathrm{mg} \mathrm{kg}^{-1}$ in the roots of hemlock and fir trees. Pastor and Bockheim ${ }^{[37]}$ observed average iron concentrations of 170 and $120 \mathrm{mg} \mathrm{kg}^{-1}$ in the roots of sugar maple and quaking aspen trees. Rodriguez-Barrueco ${ }^{[49]}$ observed average iron concentrations of $1685-5110 \mathrm{mg} \mathrm{kg}^{-1}$ in the roots of European alder trees. Young and Guinn ${ }^{[40]}$ observed average iron concentrations of 120, 308 and $293 \mathrm{mg}$ $\mathrm{kg}^{-1}$ in the roots of red spruce, white birch and red maple trees, respectively.

The statistical analysis showed that the concentrations of iron in the roots of red maple, white birch and red spruce trees in the constructed wetland were significantly greater than the concentrations of iron in roots of species in the reference site ( $\mathrm{p}$-values $=0.040,0.022$ and 0.014). Iron becomes more soluble under anaerobic soil conditions and its concentration in the roots of plants has been reported to increase with flooding ${ }^{[50,51]}$. Shrive and McBride $^{[52]}$ observed a reddish brown plaque on the root system of red maple seedlings after flooding with municipal solid waste landfill leachate. Levan and Riha ${ }^{[53]}$ reported that black spruce trees grown under flooded and non-flooded conditions had iron concentrations of 2240 and $193 \mathrm{mg} \mathrm{kg}^{-1}$ in their roots, respectively.

Seasonal variations in total iron: The seasonal variations in the average total iron concentrations in the various compartments of the different tree species are shown in Fig. 2-6. When plant samples are collected over a prolonged period of time, seasonal changes in the uptake of metals such as iron may be evident ${ }^{[41]}$. These changes could be attributed to: (a) developmental changes during the growth of the plant, (b) weather conditions that affect the evapotranspiration rate of the plant, (c) shunting of metals to plant tissues such as leaves and (d) seasonal changes in the availability of metals in the soil ${ }^{[54]}$. Tables 8-13 display the analysis of variance for the total iron concentrations in the leaves, 
Am. J. Applied Sci., 5 (9): 1091-1106, 2008

Table 8: One-way analysis of variance for the total Fe concentrations in the leaves of trees in the constructed wetland and the reference site as affected by date

\begin{tabular}{|c|c|c|c|c|c|c|c|c|c|}
\hline \multirow{2}{*}{ Source } & \multirow{2}{*}{ DF } & \multicolumn{4}{|c|}{ Wetland } & \multicolumn{4}{|c|}{ Reference } \\
\hline & & SS & MS & $\mathrm{F}$ & $\mathrm{P}$ & SS & MS & $\mathrm{F}$ & $\mathrm{P}$ \\
\hline \multicolumn{10}{|c|}{ Red maple leaves } \\
\hline Total & 14 & 116133.6 & & & & 7532.9 & & & \\
\hline Date & 4 & 76614.9 & 19153.7 & 4.847 & 0.020 & 4318.9 & 1079.7 & 3.359 & 0.055 \\
\hline Error & 10 & 39518.7 & 3951.8 & & & 3214.0 & 321.4 & & \\
\hline \multicolumn{10}{|c|}{ White birch leaves } \\
\hline Total & 14 & 19904.4 & & & & 26251.7 & & & \\
\hline Date & 4 & 6939.1 & 1734.8 & 1.338 & 0.322 & 12849.1 & 3212.3 & 2.397 & 0.120 \\
\hline Error & 10 & 12965.3 & 1296.5 & & & 13402.7 & 1340.3 & & \\
\hline \multicolumn{10}{|c|}{ Red spruce needles } \\
\hline Total & 11 & 37164.9 & & & & 98500.0 & & & \\
\hline Date & 3 & 6901.6 & 2300.5 & 0.608 & 0.628 & 40090.0 & 13363.3 & 1.830 & 0.220 \\
\hline Error & 8 & 30263.3 & 3782.9 & & & 58410.0 & 7301.3 & & \\
\hline
\end{tabular}

Differences are considered significant at a p-value $\leq 0.05$ (95\% confidence interval)

Table 9: One-way analysis of variance for the total Fe concentrations in the twigs of trees in the constructed wetland and the reference site as affected by date

\begin{tabular}{|c|c|c|c|c|c|c|c|c|c|}
\hline \multirow{2}{*}{ Source } & \multirow{2}{*}{ DF } & \multicolumn{4}{|c|}{ Wetland } & \multicolumn{4}{|c|}{ Reference } \\
\hline & & SS & MS & $\mathrm{F}$ & $\mathrm{P}$ & SS & MS & $\mathrm{F}$ & $\mathrm{P}$ \\
\hline \multicolumn{10}{|c|}{ Red maple twigs } \\
\hline Total & 11 & 219712.7 & & & & 331086.7 & & & \\
\hline Date & 3 & 153662.0 & 51220.7 & 6.204 & 0.018 & 177864.7 & 59288.2 & 3.096 & 0.089 \\
\hline Error & 8 & 66050.7 & 8256 & & & 153222.0 & 19152.8 & & \\
\hline \multicolumn{10}{|c|}{ White birch twigs } \\
\hline Total & 11 & 128944.7 & & & & 121152.0 & & & \\
\hline Date & 3 & 96502.0 & 32167.3 & 7.932 & 0.009 & 115414.7 & 38471.6 & 53.644 & 0.000 \\
\hline Error & 8 & 32442.7 & 4055.3 & & & 5737.3 & 717.2 & & \\
\hline \multicolumn{10}{|c|}{ Red spruce twigs } \\
\hline Total & 11 & 100592.9 & & & & 81780.9 & & & \\
\hline Date & 3 & 14620.9 & 4873.6 & 0.454 & 0.722 & 16108.9 & 5369.6 & 0.654 & 0.603 \\
\hline Error & 8 & 85972.0 & 10746.5 & & & 65672.0 & 8209.0 & & \\
\hline
\end{tabular}

Differences are considered significant at a p-value $\leq 0.05$ (95\% confidence interval)

Table 10: One-way analysis of variance for the total Fe concentrations in the branches of trees in the constructed wetland and the reference site as affected by date

\begin{tabular}{|c|c|c|c|c|c|c|c|c|c|}
\hline \multirow{2}{*}{ Source } & \multirow{2}{*}{ DF } & \multicolumn{4}{|c|}{ Wetland } & \multicolumn{4}{|c|}{ Reference } \\
\hline & & SS & MS & $\mathrm{F}$ & $P$ & SS & MS & $\mathrm{F}$ & $P$ \\
\hline \multicolumn{10}{|c|}{ Red maple branches } \\
\hline Total & 11 & 71152.9 & & & & 22156.9 & & & \\
\hline Date & 3 & 18624.9 & 6208.3 & 0.946 & 0.463 & 13908.9 & 4636.3 & 4.497 & 0.040 \\
\hline Error & 8 & 52528.0 & 6566.0 & & & 8248.0 & 1031.0 & & \\
\hline \multicolumn{10}{|c|}{ White birch branches } \\
\hline Total & 11 & 36545.7 & & & & 14284.9 & & & \\
\hline Date & 3 & 11091.7 & 3697.2 & 1.162 & 0.382 & 2948.3 & 982.8 & 0.694 & 0.581 \\
\hline Error & 8 & 25454.0 & 3181.8 & & & 11336.7 & 1417.1 & & \\
\hline \multicolumn{10}{|c|}{ Red spruce branches } \\
\hline Total & 11 & 61106.0 & & & & 41203.7 & & & \\
\hline Date & 3 & 25698.7 & 8566.2 & 1.935 & 0.202 & 7191.0 & 2397.0 & 0.564 & 0.654 \\
\hline Error & 8 & 35407.3 & 4425.9 & & & 34012.7 & 4251.6 & & \\
\hline
\end{tabular}


Am. J. Applied Sci., 5 (9): 1091-1106, 2008

Table 11: One-way analysis of variance for the total Fe concentrations in the trunk wood of trees in the constructed wetland and the reference site as affected by date

\begin{tabular}{|c|c|c|c|c|c|c|c|c|c|}
\hline \multirow{2}{*}{ Source } & \multirow{2}{*}{ DF } & \multicolumn{4}{|c|}{ Wetland } & \multicolumn{4}{|c|}{ Reference } \\
\hline & & SS & MS & $\mathrm{F}$ & $\mathrm{P}$ & SS & MS & $\mathrm{F}$ & $\mathrm{P}$ \\
\hline \multicolumn{10}{|c|}{ Red maple trunk wood } \\
\hline Total & 11 & 72604.0 & & & & 273252.7 & & & \\
\hline Date & 3 & 54406.7 & 18135.5 & 7.973 & 0.009 & 238075.3 & 79358.4 & 18.048 & 0.001 \\
\hline Error & 8 & 18197.3 & 2274.7 & & & 35177.3 & 4397.2 & & \\
\hline \multicolumn{10}{|c|}{ White birch trunk wood } \\
\hline Total & 11 & 195750.9 & & & & 114705.7 & & & \\
\hline Date & 3 & 71748.9 & 23916.3 & 1.543 & 0.277 & 56680.3 & 18893.4 & 2.605 & 0.124 \\
\hline Error & 8 & 124002.0 & 15500.3 & & & 58025.3 & 7253.2 & & \\
\hline \multicolumn{10}{|c|}{ Red spruce trunk wood } \\
\hline Total & 11 & 28526.9 & & & & 68705.7 & & & \\
\hline Date & 3 & 24248.3 & 8082.8 & 15.113 & 0.001 & 62121.0 & 20707.0 & 25.158 & 0.000 \\
\hline Error & 8 & 4278.7 & 534.8 & & & 6584.7 & 823.1 & & \\
\hline
\end{tabular}

Table 12: One-way analysis of variance for the total Fe concentrations in the trunk bark of trees in the constructed wetland and the reference site as affected by date

\begin{tabular}{|c|c|c|c|c|c|c|c|c|c|}
\hline \multirow{2}{*}{ Source } & \multirow{2}{*}{$\mathrm{DF}$} & \multicolumn{4}{|c|}{ Wetland } & \multicolumn{4}{|c|}{ Reference } \\
\hline & & SS & MS & $\mathrm{F}$ & $\mathrm{P}$ & SS & MS & $\mathrm{F}$ & $\mathrm{P}$ \\
\hline \multicolumn{10}{|c|}{ Red maple trunk bark } \\
\hline Total & 11 & 64778.7 & & & & 76137.7 & & & \\
\hline Date & 3 & 28566.7 & 9522.2 & 2.104 & 0.178 & 48321.0 & 16107.0 & 4.632 & 0.037 \\
\hline Error & 8 & 36212.0 & 4526.5 & & & 27816.7 & 3477.1 & & \\
\hline \multicolumn{10}{|c|}{ White birch trunk bark } \\
\hline Total & 11 & 221056.7 & & & & 114760.3 & & & \\
\hline Date & 3 & 69785.3 & 23261.3 & 1.230 & 0.360 & 65960.9 & 21986.9 & 3.604 & 0.065 \\
\hline Error & 8 & 151271.3 & 18908.9 & & & 48799.3 & 6099.9 & & \\
\hline \multicolumn{10}{|c|}{ Red spruce trunk bark } \\
\hline Total & 11 & 265816.0 & & & & 71004.9 & & & \\
\hline Date & 3 & 192504.7 & 64168.2 & 7.002 & 0.013 & 19664.9 & 6554.9 & 1.021 & 0.433 \\
\hline Error & 8 & 4278.7 & 9163.9 & & & 51340.0 & 6417.5 & & \\
\hline
\end{tabular}

Table 13: One-way analysis of variance for the total Fe concentrations in the roots of trees in the constructed wetland and the reference site as affected by date

\begin{tabular}{|c|c|c|c|c|c|c|c|c|c|}
\hline \multirow{2}{*}{ Source } & \multirow{2}{*}{$\mathrm{DF}$} & \multicolumn{4}{|c|}{ Wetland } & \multicolumn{4}{|c|}{ Reference } \\
\hline & & SS & MS & $\mathrm{F}$ & $\mathrm{P}$ & SS & MS & $\mathrm{F}$ & $\mathrm{P}$ \\
\hline \multicolumn{10}{|c|}{ Red maple roots } \\
\hline Total & 5 & 5969527 & & & & 112874.8 & & & \\
\hline Date & 1 & 4754380 & 4754380.2 & 15.650 & 0.017 & 40837.5 & 40837.5 & 2.268 & 0.207 \\
\hline Error & 4 & 1215147 & 303786.7 & & & 72037.3 & 18009.3 & & \\
\hline \multicolumn{10}{|c|}{ White birch roots } \\
\hline Total & 5 & 949257.3 & & & & 15181.3 & & & \\
\hline Date & 1 & 388112.7 & 388112.7 & 2.767 & 0.172 & 1600.7 & 1600.7 & 0.471 & 0.530 \\
\hline Error & 4 & 561144.7 & 140286.2 & & & 13580.7 & 3395.2 & & \\
\hline \multicolumn{10}{|c|}{ Red spruce roots } \\
\hline Total & 5 & 2409665 & & & & 21502.0 & & & \\
\hline Date & 1 & 67416.0 & 67416.0 & 0.115 & 0.751 & 4930.7 & 4930.7 & 1.190 & 0.337 \\
\hline Error & 4 & 2342249 & 585562.3 & & & 16571.3 & 4142.8 & & \\
\hline
\end{tabular}


twigs, branches, trunk wood, trunk bark and roots of trees in the constructed wetland and the reference site as affected by the sampling date.

Leaves: The average iron concentrations in the leaves of red maple trees in the constructed wetland were significantly affected by the sampling date ( $\mathrm{p}$-value $=0.020)$ and displayed an increasing trend towards the end of the growing season with a maximum iron concentration of $321 \pm 117 \mathrm{mg} \mathrm{kg}^{-1}$ in August 2006 . A similar pattern was observed for red maple trees in the reference site at a confidence interval of $90 \%$ ( $\mathrm{p}$-value $=0.055)$ where the average concentration of iron in the leaves reached a minimum value of $102 \pm 24 \mathrm{mg} \mathrm{kg}^{-1}$ in July 2006. The average iron concentrations in the leaves of white birch and red spruce trees in the constructed wetland and the reference site were not affected by the sampling date.

Mertens et al. ${ }^{[54]}$ and Laureysens et al. ${ }^{[55]}$ stated that the accumulation of iron in the leaves of deciduous trees, such as red maple trees in the present study, prior to leaf senescence was an excretion mechanism of excess metals by the trees. The accumulation of iron in the leaves of Norway maple and white birch trees in urban areas of Poland during the growing season was observed by Piczak et al. ${ }^{[33]}$ who reported increased concentrations of iron in the leaves of maple and birch trees from 196 and $160 \mathrm{mg} \mathrm{kg}^{-1}$ in June to 300 and $245 \mathrm{mg} \mathrm{kg}^{-1}$ in October, respectively. RodriguezBarrueco et al. ${ }^{[49]}$ observed an accumulation of iron in the leaves of European alder trees in Spain prior to leaf senescence and reported an increased average concentration of iron in the leaves from $314 \mathrm{mg}$ $\mathrm{kg}^{-1}$ in April to $404 \mathrm{mg} \mathrm{kg}^{-1}$ in November. Lea et al. ${ }^{[56]}$ noted an accumulation of iron in the leaves of yellow birch trees in New York during the growing season and reported an increased average concentration of iron in the leaves from $67.60 \pm 24.13$ $\mathrm{mg} \mathrm{kg}^{-1}$ in June to $106.91 \pm 38.53 \mathrm{mg} \mathrm{kg}^{-1}$ in October.

Twigs: The average iron concentrations in the twigs of red maple trees in the constructed wetland and the reference site were significantly affected by the sampling date (p-values $=0.018$ and 0.089 ) at a $95 \%$ and a $90 \%$ confidence interval, respectively, with the highest iron concentrations in September 2005 of $348 \pm 154 \mathrm{mg} \mathrm{kg}^{-1}$ and $355 \pm 275 \mathrm{mg} \mathrm{kg}^{-1}$ and in June 2006 of $242 \pm 87 \mathrm{mg} \mathrm{kg}^{-1}$ and $164 \pm 29 \mathrm{mg} \mathrm{kg}^{-1}$. A similar pattern was observed for white birch trees in the constructed wetland and the reference site where the average iron concentration in the twigs reached maximum concentrations of $282 \pm 121 \mathrm{mg} \mathrm{kg}^{-1}$ and $76 \pm 35 \mathrm{mg} \mathrm{kg}^{-1}$ in September 2005 and June 2006 and $304 \pm 37 \mathrm{mg} \mathrm{kg}^{-1}$ in September 2005. The average iron concentrations in the twigs of red spruce trees in the constructed wetland and the reference site were not significantly affected by the sampling date.

The maximum concentrations of iron in the twigs in June 2006 could be attributed to a high metal uptake compared to growth rate at the beginning of the growing season. This was followed by a period of active growth, which diluted the iron concentrations ${ }^{[54]}$. Ferm and Markkola ${ }^{[57]}$ observed a maximum iron concentration during the growing season in the twigs of 1 year old and 15 year old downy birch trees of approximately $150 \mathrm{mg} \mathrm{kg}^{-1}$ in the months of June and July.

Branches: The average iron concentration in the branches of red maple trees in the constructed wetland was not significantly affected by the sampling date. The average iron concentration in the branches of red maple trees in the reference site was significantly affected by the sampling date ( $\mathrm{p}$-value $=0.040$ ) and displayed a maximum value in June 2006 of $115 \pm 59 \mathrm{mg} \mathrm{kg}^{-1}$. The average concentrations of iron in the branches of white birch and red spruce trees in the constructed wetland and the reference site were not significantly affected by the sampling date. A review of the literature revealed no specific studies on the seasonal variability of iron in tree branches.

Trunk wood: The average concentrations of iron in the trunk wood of red maple and red spruce trees in the constructed wetland were significantly affected by the sampling date with maximum concentrations of $205 \pm 28$ $\mathrm{mg} \mathrm{kg}$ and $142 \pm 10 \mathrm{mg} \mathrm{kg}^{-1}$ in September 2005. A similar pattern was observed for red maple and red spruce trees in the reference site where the average concentration of iron in the trunk wood reached maximum values of $362 \pm 130$ and $196 \pm 46 \mathrm{mg} \mathrm{kg}^{-1}$ in September 2005. The average concentrations of iron in the trunk wood of white birch trees in the constructed wetland and the reference site were not significantly affected by the sampling date.

A review of the literature revealed one study by Laureysens et al. ${ }^{[5]}$ who reported that the average iron concentration in the wood of poplar clones did not significantly increase or decrease during the growing season. In the present study, if the data from September 2005 is removed from the statistical analysis, then the concentrations of iron in the trunk wood of red maple, white birch and red spruce trees were not significantly affected by the sampling date. 
Trunk bark: The average iron concentrations in the trunk bark of red maple and white birch trees in the constructed wetland were not significantly affected by the sampling date. The average iron concentrations in the trunk bark of red maple and white birch trees in the reference site were significantly affected by the sampling date at a $95 \%$ and a $90 \%$ confidence interval $(\mathrm{p}$-values $=0.037$ and 0.065$)$, respectively with maximum concentrations of $147 \pm 43 \mathrm{mg} \mathrm{kg}^{-1}$ and $253 \pm 90 \mathrm{mg} \mathrm{kg}^{-1}$ in September 2005 and July 2006 for maple and $244 \pm 140 \mathrm{mg} \mathrm{kg}^{-1}$ and $159 \pm 34 \mathrm{mg} \mathrm{kg}^{-1}$ in June 2006 and July 2006 for birch. The average iron concentration in the trunk bark of red spruce trees in the constructed wetland was significantly affected by the sampling date ( $\mathrm{p}$-value $=0.013$ ) with maximum values of $424 \pm 50 \mathrm{mg} \mathrm{kg}^{-1}$ and $316 \pm 163 \mathrm{mg} \mathrm{kg}^{-1}$ in September 2005 and July 2006. The average iron concentration in the trunk bark of red spruce trees in the reference site was not significantly affected by the sampling date. A review of the literature revealed no specific studies on the seasonal variability of iron in the trunk bark of trees.

Roots: The average iron concentrations in the roots of red maple trees in the constructed wetland in August 2006 were significantly greater than in September 2005 $(\mathrm{p}$-value $=0.017)$ with a maximum concentration of $2091 \pm 763 \mathrm{mg} \mathrm{kg}^{-1}$. The average iron concentration in the roots of red maple trees in the reference site, white birch and red spruce trees in the constructed wetland and the reference site were not affected by the sampling date.

A review of the literature revealed no specific studies on the seasonal variability of iron in the roots of trees. However, significant differences in the concentration of iron in the roots of red maple in August 2006 could be attributed to exposure of the roots to flooded soil conditions for a longer period of time.

Iron distribution within trees: Fig. 7 displays the percent distribution of iron in the above and belowground compartments of wetland and reference tree species in August 2006. It is clear that red maple, white birch and red spruce trees in the constructed wetland retain a major portion of their overall iron concentration in their root systems. Under flooded soil conditions, some species have the ability to transfer oxygen from their aboveground compartments to their roots creating a thin oxidized layer around the surface of their roots ${ }^{[58]}$. At a pH greater than 3.5 with oxygen present, soluble and bioavailable ferrous iron is oxidized to insoluble ferric iron which cannot be readily taken up by plants and may accumulate on the outside surface of the roots ${ }^{[59,60]}$. Consequently, the concentration of iron in the roots is quite high when compared to aboveground plant parts. As a result, the trees that were exposed to flooded soil conditions were able to exclude high concentrations of iron in their aboveground tissues.
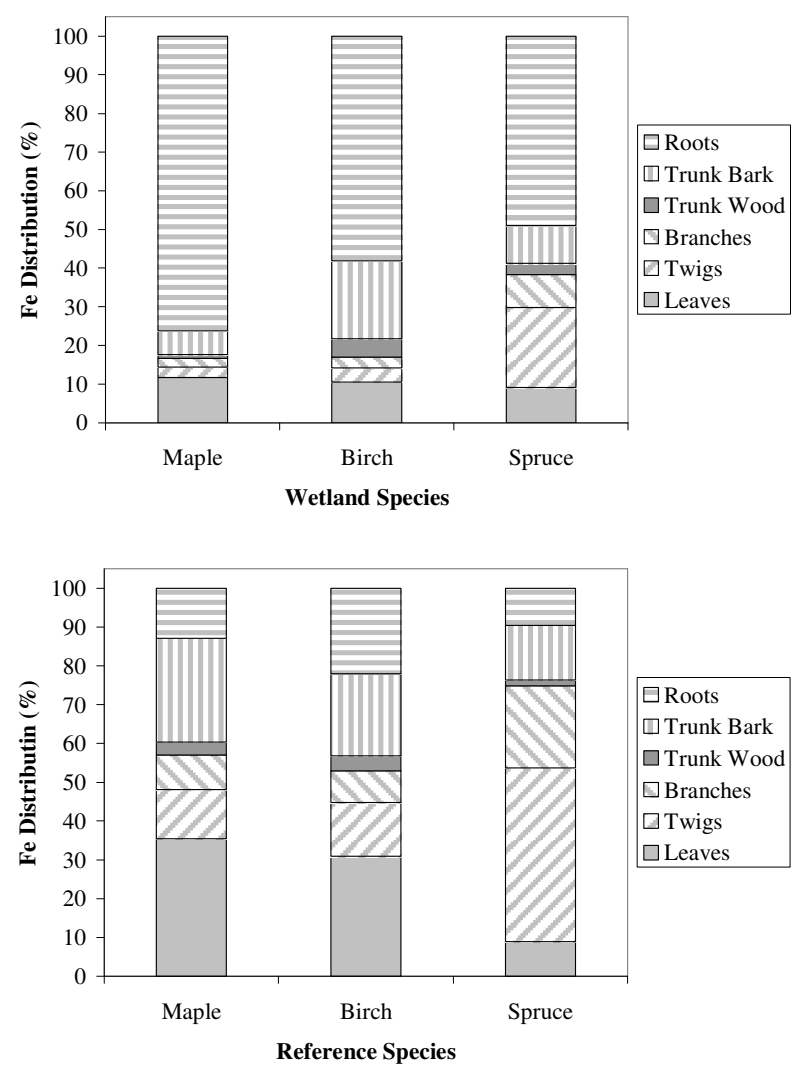

Fig. 7: Fe distribution (\%)

In aboveground compartments, iron was present in higher concentrations in the leaves and trunk bark of red maple and white birch trees in the constructed wetland and the reference site in August 2006. Higher concentrations of iron in the leaves and trunk bark of mature white birch trees were also observed by Schmitt et $a l .{ }^{[46]}$ and Young and Guinn ${ }^{[40]}$. Morrison and Hogan $^{[42]}$ and Pastor and Bockheim ${ }^{[37]}$ observed higher concentrations of iron in the leaves and trunk bark of sugar maple trees in Ontario and Northern Wisconsin, respectively.

Iron was present in higher concentrations in the trunk bark of species compared to the trunk wood. In the constructed wetland, the average concentrations of iron in the trunk bark of trees were 1.6-3.8 fold higher than the trunk wood concentrations. In the reference site, the average concentrations of iron in the trunk bark 
were 1.2-2.2 fold higher than the trunk wood concentrations. Morrison and $\operatorname{Hogan}^{[42]}$, Schmitt et al. ${ }^{[46]}$ and Wittwer et al. ${ }^{[43]}$ observed a 2.8 fold, 3.3 fold and a 9.2 fold increase in the concentrations of iron in the trunk bark of sugar maple, white birch and red pine trees, respectively compared to the trunk wood concentrations. Young and Guinn ${ }^{[40]}$ observed a 5.9 fold, 5.5 fold and a 5.0 fold increase in the concentrations of iron in the trunk bark of red spruce, white birch and red maple trees, respectively compared to the trunk wood concentrations.

\section{CONCLUSIONS}

The average iron concentrations in the aboveground compartments of red maple, white birch and red spruce trees were within the range of iron concentrations reported in the literature for these trees regardless of the sampling location. The concentrations of iron in the roots of red maple, white birch and red spruce trees in the constructed wetland were significantly greater than those in the roots of the same species in the reference site because of the flooded soil conditions in the constructed wetland. The sampling date had a significant impact on the concentration of iron in the compartments of different tree species. The average iron concentrations in the leaves of red maple trees in the constructed wetland and the reference site displayed an increasing trend towards the end of the growing season, which could be attributed to an excretion mechanism of excess metals by the trees. The average iron concentrations in the twigs of red maple and white birch trees in the constructed wetland and the reference site displayed maximum concentrations at the beginning of the growing season, which could be attributed to a high metal uptake compared to growth rate. Red maple, white birch and red spruce trees in the constructed wetland retained a major portion of their overall iron concentration in their root systems. In aboveground compartments, higher concentrations of iron were present in the leaves and trunk bark of species on both the constructed wetland and the reference site. Iron was present in higher concentrations in the trunk bark of species compared to the trunk wood. In the constructed wetland, the average concentrations of iron in the trunk bark of trees were 1.6-3.8 fold higher than the trunk wood concentrations while in the reference site, the average concentrations of iron in the trunk bark were 1.2-2.2 fold higher than the trunk wood concentrations.

\section{ACKNOWLEDGEMENTS}

This research was funded by the ELJB Foundation of Montreal and Environment Canada.

\section{REFERENCES}

1. Ernst, W.H.O., 1998. The origin and ecology of contaminated, stabilized and non-pristine soils. In: Vangronsveld, J. and S.D. Cunningham (Eds.). Metal-Contaminated Soils: In Situ Inactivation and Phytorestoration. Springer-Verlag, New York, pp: 17-29.

2. Vangronsveld, J. and S.D. Cunningham, 1998. Introduction to the concepts. In: Vangronsveld, J. and S. D. Cunningham (Eds). Metal-Contaminated Soils: In Situ Inactivation and Phytorestoration. Springer-Verlag, New York, New York. pp: 1-12.

3. Baker, A.J.M., S.P. McGrath, C.M.D. Sidoli and R.D. Reeves, 1994. The possibility of in situ heavy metal decontamination of polluted soils using crops of metal-accumulating plants. Resources, Conservation and Recycling, 11: 41-49.

4. Siegel, F.R., 2002. Environmental Geochemistry of Potentially Toxic Metals. Springer-Verlag, Berlin, Germany.

5. Alloway, B.J. and D.C. Ayres, 1993. Chemical Principles of Environmental Pollution. Blackie Academic \& Professional, New York.

6. Moore, J.W., 1991. Inorganic Contaminants of Surface Water. Springer-Verlag, New York.

7. Cooper, E.M., J.T. Sims, S.D. Cunningham, J.W. Huang and W.R. Berti, 1999. Chelate assisted phytoextraction of lead from contaminated soils. J. of Envir. Quality, 28: 1709-1719.

8. Smith, A. Lawrence, L. Jeffrey Means, Abraham Chen, Bruce Alleman, C. Christopher Chapman, S. John Jr. Tixier, E. Susan Brauning, R. Arun Gavaskar and D. Micheal Royer, 1995. Remedial Options for Metals-Contaminated Sites. CRC Press, Boca Raton, Florida.

9. USEPA., 1999. Phytoremediation Resource Guide. Retrieved on May 16, 2005, from http://www.epa.gov/tio/download/remed/phytoresg ude.pdf

10. Mills, H.A. and J.B. Jones, Jr. 1996. Plant Analysis Handbook II: A Practical Sampling, Preparation, Analysis, and Interpretation Guide. MicroMacro Publishing Inc., Athens, Georgia.

11. Marschner, H., 1995. Mineral Nutrition of Higher Plants. Harcourt Brace \& Company, New York.

12. Xue, S.G., Y.X. Chen, A.J.M. Baker, R.D. Reeves, X.H. Xu and Q.Lin, 2005. Manganese uptake and accumulation by two populations of Phytolacca acinosa ROXB (Phytolaccaceae). Water, Air, and Soil Pollution, 160: 3-14.

13. Brooks, R.R., A.W. Howes, J.H. Kirkman and P.E.H. Gregg, 1997. The potential of the high biomass nickel hyperaccumulator Berkheya coddii for phytoremediation and phytomining. J. of Geochem. Exp., 60: 115-126. 
14. Baker, A.J.M., R.D. Reeves and S.P. McGrath, 1991. In situ decontamination of heavy metal polluted soils using crops of metal-accumulating plants-a feasibility study. In: R.E. Hinchee, and R.F. Olfenbuttel (Eds). In Situ Bioreclamation: Applications and Investigations for Hydrocarbon and Contaminated Site Remediation. Battelle Press, Columbus, Ohio. pp: 600-605.

15. Chen, Y., X. Li and Z. Chen, 2004. Leaching and uptake of heavy metals by 10 different species of plants during an EDTA-assisted phytoextraction process. Chemosphere, 57: 187-196.

16. Huang, J.W., J. Chen, W.R. Berti and S.D. Cunningham, 1997. Phytoremediation of lead contaminated soils: Role of synthetic chelates in lead phytoextraction. Environmental Science and Technology, 31: 800-805.

17. Mkandawire, M. and E.G. Dudel, 2005. Accumulation of arsenic in Lemna gibba L. (duckweed) in tailing waters of two abandoned uranium mining sites in Saxony, Germany. Sci. of the Total Envir., 336: 81-89.

18. Zhu, Y.L., A.M. Zayad, J.H. Qian, M.de Souza and N. Terry, 1999. Phytoaccumulation of trace elements by wetland plants II. Water hyacinth. J. Envir. Quality, 28: 339-344.

19. Pulford, I.D., C. Watson and S.D. McGregor, 2001. Uptake of chromium by trees: prospects for phytoremediation. Environmental Geochemistry and Health, 23: 307-311.

20. Robinson, B.H., T.M. Mills, D. Petit, L.E. Fung, S.R. Green and B.E. Clothier, 2000. Natural and induced cadmium-accumulation in poplar and willow: implications for phytoremediation. Plant and Soil, 227: 301-306.

21. Lepp, N.M, 1995. Uptake, mobility and loci of concentration of heavy metals in trees. In: Glimmerveen, I. (Eds). Heavy Metals and Trees. Institute of Chartered Foresters, Glasgow, Scotland. pp: 68-82.

22. Kopponen, P., M. Utriainem, K. Lukkari, S. Suntioinen, L. Karenlampi and S. Karenlampi, 2001. Clonal differences in copper and zinc tolerance in birch in metal-supplemented soils. Environmental Pollution, 112: 89-97.

23. Klang-Westin, E. and J. Eriksson, 2003. Potential of Salix as phytoextractor for Cd on moderately contaminated soils. Plant and Soil, 249:127-137.

24. CCME, 2005. Canadian Environmental Quality Guidelines. Canadian Council of Ministers of the Environment, Winnipeg, Manitoba. Retrieved on August 20, 2006, from http://www.ccme.ca
25. BCMELP, 2001. Ambient Water Quality Guidelines for Manganese. British Columbia Ministry of Environment, Lands and Parks, Vancouver, British Columbia. Retrieved September 14, 2002, from http://wlapwww.gov.bc.ca/wat/wq/BCguidelines/m anganese.html

26. MacDougall, J.I., D.B. Cann and J.D. Hilchey, 1963. Soil survey of Halifax County, Nova Scotia. Retrieved on February 27, 2007, from http://www.sis.agr.gc.ca.

27. Canadian Forest Service, 1994. Canada's National Forest Health Monitoring Plot Network: Foliage Sampling and Analysis. Canadian Forest Services, Ottawa, Ontario. Retrieved on May 30, 2005, from http://www.eman-rese.ca

28. Horwitz, W., 2000. Official methods of analysis of AOAC International. 17th edition. AOAC International, Arlington, Virginia.

29. Westerman, R.L., 1990. Soil testing and plant analysis. 3rd edition. Soil Science Society of America, Madison, Wisconsin.

30. Decoteau, D.R., 2005. Principles of Plant Science. Pearson Prentice Hall, Upper Saddle River, New Jersey. Pp: 318-320.

31. Schmidt, W., 1999. Review mechanisms and regulation of reduction-based iron uptake in plants. New Phytologist, 141: 1-26.

32. Moorhead, K.K. and J.V. McArthur, 1996. Spatial and temporal patterns of nutrient concentrations in foliage of riparian species. American Midland Naturalist, 136: 29-41.

33. Piczak, K., A. Lesniewicz and W. Zyrnicki, 2003. Metal concentrations in deciduous tree leaves from urban areas in Poland. Environmental Monitoring and Assessment, 86: 273-287.

34. Kozlov, M.V., E. Haukioja, A.V. Bakhtiarov and D.N. Stroganov, 1995. Heavy metals in birch leaves around a nickel-copper smelter at Monchegorsk, Northwestern Russia. Envir. Pollution, 90: 291-299.

35. Heinrichs, H. and R. Mayer, 1980. The role of forest vegetation in the biogeochemical cycle of heavy metals. J. Envir. Quality, 9: 111-118.

36. Reeves, R.D. and A.J.M. Baker, 2000. Metal-accumulating plants. In: Raskin, I. and B.D. Ensley (Eds). Phytoremediation of Toxic Metals: Using Plants to Clean Up the Environment. John Wiley \& Sons Inc., New York. pp: 193-230.

37. Pastor, J. and J.G. Bockheim. 1984. Distribution and cycling of nutrients in an aspen-mixedhardwood-spodosol ecosystem in Northern Wisconsin. Ecology, 65: 339-353. 
38. McColl, J.G., 1981. Trace elements in the hydrologic cycle of a forest ecosystem. Plant and Soil, 62: 337-349.

39. Brotherson, J.D. and S.T. Osayande, 1980. Mineral concentrations in true mountain mahogany and Utah juniper, and in associated soils. J. Range Management, 33: 182-185.

40. Young, H.E. and V.P. Guinn, 1966. Chemical elements in complete mature trees of seven species in Maine. Tappi, 49: 190-197.

41. Sailerova, E. and M.A. F. Fedikow, 2004. The effects of seasonal changes, sample site drainage and tree morphology on trace element contents of black spruce (Picea mariana) crown twigs and outer bark. Geochemistry: Exploration, Envir. Analysis, 4: 365-379.

42. Morrison, I.K. and G.D. Hogan, 1986. Trace element distribution within the tree phytomass and forest floor of a tolerant hardwood stand, Algoma, Ontario. Water, Air, and Soil Pollution, 31: 493-500.

43. Wittwer, R.F., A.L. Leaf and D.H. Bickelhaupt, 1975. Biomass and chemical composition of fertilized and/or irrigated Pinus resinosa plantations. Plant and Soil, 42: 629-651.

44. Miller, R.B., 1999. Structure of Wood. In: Wood handbook-Wood as an engineering material. United States Department of Agriculture, Forest Service, Forest Products Laboratory, Madison, Wisconsin. pp: 2.1-2.4.

45. Esch, M., D. Hofmann, G. Krebs, C. Thierfelder, R. Wunsch, R. Maier, M. Kuzel, M. Schosnig and K.O. Groeneveld, 1996. Elemental composition of different types of wood. Nuclear Instruments and Methods in Physics Res. B, 109: 328-331.

46. Schmitt, M.D.C., M.M. Czapowskyj, L.O. Safford and A.L. Leaf, 1981. Biomass and element uptake in fertilized and unfertilized Betula papyrifera and Populus grandidentata. Plant and Soil, 60: 111-121.

47. Saarela, K.E., L. Harju, J. Rajander, J.O. Lill, S.J. Heselius, A. Lindroos and K. Mattsson, 2005. Elemental analyses of pine bark and wood in an environmental study. Science of the Total Environment, 343: 231-241.

48. Vogt, K.A., R. Dahlgren, F. Ugolini, D. Zabowski, E.E. Moore and R. Zasoski, 1987. Aluminum, Fe, $\mathrm{Ca}, \mathrm{Mg}, \mathrm{K}, \mathrm{Mn}, \mathrm{Cu}, \mathrm{Zn}$ and $\mathrm{P}$ in above and belowground biomass. I. Abies amabilis and Tsuga mertensiana. Biogeochemistry, 4: 277-294.

49. Rodriguez-Barrueco, C., C. Miguel and P. Subramaniam, 1984. Seasonal fluctuations of the mineral concentration of alder (Alnus glutinosa (L.) Gaertn.) from the field. Plant and Soil, 78: 201-208.
50. De Simone, O., E. Muller, W.J. Junk, K. Richau and W. Schmidt, 2003. Iron distribution in three central Amazon tree species from whitewater-inundation areas subjected to different iron regimes. Trees-Structure and Function, 17: 535-541.

51. Harrington, C.A., 1987. Responses of red alder and black cottonwood seedlings to flooding. Physiologia Plantarum, 69: 35-48.

52. Shrive, S.C. and A. McBride, 1995. Physiological responses of red maple saplings to sub-irrigation with an untreated municipal landfill leachate. Waste Management and Res., 13: 219-239.

53. Levan, M.A. and S.J. Riha, 1986. The precipitation of black oxide coatings on flooded conifer roots of low internal porosity. Plant and Soil, 95: 33-42.

54. Mertens, J., P. Vervaeke, E. Meers and F.M.G. Tack, 2006. Seasonal changes of metals in willow (Salix sp.) stands for phytoremediation on dredged sediment. Environmental Science and Technology, 40: 1962-1968.

55. Laureysens, I., R. Blust, L. De Temmerman, C. Lemmens and R. Ceulemans, 2004. Clonal variation in heavy metal accumulation and biomass production in a poplar coppice culture: I. Seasonal variation in leaf, wood and bark concentrations. Environmental Pollution, 131: 485-494.

56. Lea, R., W.C. Tierson, D.H. Bickelhaupt and A.L. Leaf, 1979. Stand treatment and sampling time of hardwood foliage. II. Micro-element analysis. Plant and Soil, 51: 535-550.

57. Ferm, A. and A. Markkola, 1985. Nutritional variation of leaves, twigs and buds in Betula pubescens stands during the growing season. Folia Forestalia, 613: 1-28.

58. Kozlowski, T.T., 1997. Responses of woody plants to flooding and salinity. Tree Physiology Monograph, 1: 1-29.

59. Blaylock, M. and J.W. Huang, 2000. Phytoextraction of metals. In: Raskin, I. and B.D. Ensley (Eds). Phytoremediation of Toxic Metals: Using Plants to Clean Up the Environment. John Wiley \& Sons Inc., New York pp: 53-70.

60. Fisher, H.M and E.L. Stone, 1991. Iron oxidation at the surface of slash pine roots from saturated soils. Soil Science Society of Am. J., 55: 11231129 . 